\title{
Carbon isotope study on Celtic graphite- tempered archaeological ceramics from the South Transdanubian region (Hungary)
}

\author{
Izabella Havancsák, József Fekete, \\ Bernadett Bajnóczi \\ Institute for Geochemical Research, \\ Hungarian Academy of Sciences, Budapest
}

\begin{abstract}
The paper presents an application of carbon isotope analysis in the archaeometric research of graphite-tempered ceramics. Graphite separated from Celtic graphitic ceramics were analysed from Szû́r, Szajk and Dunaszentgyörgy archaeological sites from the South Transdanubian region of Hungary. Variation in $\delta^{13} \mathrm{C}$ values of graphite in the sampling sites is attributed to the characteristics of graphitic metamorphic rock used for tempering. The carbon isotope results will serve as basis for further provenance research on graphite.
\end{abstract}

Key words: graphite, Celtic graphitic ceramics, graphitic gneiss, temper, carbon isotope, $\delta^{13} \mathrm{C}$

\section{Introduction}

The Celtic graphitic ceramic is a distinctive type of pottery tempered with graphite and known from most part of the Central European Celtic world. In the area of Hungary graphitic pots were produced in great numbers from the middle La Tène period (Szabó et al. 1999) until the decline of the Celtic dominion (1st cent. A.D.). Graphitic ceramics can be found in a wide geographical area, not only around the graphite sources, which suggests extended trade. Former results, based on the mineralogical and petrographic analyses carried out on graphitic ceramics from Hungary (Havancsák et al. 2009a, b), suggest that the studied ceramics were tempered with graphitic, medium- to high-grade metamorphic gneiss. This graphitic gneiss cannot be found in outcrops in the area of Hungary.

Addresses: I. Havancsák, J. Fekete, B. Bajnóczi: H-1112 Budapest, Budaörsi út 45, Hungary Corresponding author: havancsaki@geochem.hu

Received: April 26, 2011; accepted: May 16, 2011 
Our study is an example for utilizing carbon isotope analysis, a technique that is commonly used in geological research, on graphite temper of archaeological graphitic ceramics. The main aim of the overall work is to investigate the carbon isotope composition of graphite in the pottery and compare them with that of graphitic host rocks from the potential source regions. In this paper we present the first results of the carbon isotope analysis performed on graphitic ceramics from Hungary.

\section{Sample description}

The 32 graphitic ceramics were analysed from three archaeological sites: Dunaszentgyörgy (LT B2-C1, 11 sherds), Szû́r (LT D, 14 sherds) and Szajk (LT B2C1, 7 sherds), which are located in South Hungary on the flood plain of river Danube. The graphitic ceramics belong to situla-type sherds (thick wall, swollen rim). They were tempered with graphitic metamorphic rock. Graphite grains appear as opaque, individual fresh flakes and in lithoclasts with silicate minerals. The sherds show great variability in the amount and size of graphite from $\sim 5$ to $50 \%$ and between very fine and coarse grains (from few $\mu \mathrm{m}$ up to $5 \mathrm{~mm}$ ), respectively. For their detailed archaeometric and petrographic description see Havancsák et al. (2009a, b).

\section{Methods}

The sherds chosen for isotope analysis were pulverized and treated with $10 \%$ acetic acid to remove carbonate. After being leached three times the samples were centrifuged and dried at $40{ }^{\circ} \mathrm{C}$. The separated graphite samples were oxidized with copper oxide in evacuated quartz tubes closed with a Teflon valve at $950{ }^{\circ} \mathrm{C}$ based on the method of Sofer (1980). The evolved $\mathrm{H}_{2} \mathrm{O}$ and $\mathrm{CO}_{2}$ were separated online by cold traps using liquid nitrogen and ethyl alcohol cooled below $-80{ }^{\circ} \mathrm{C}$. The ${ }^{13} \mathrm{C} /{ }^{12} \mathrm{C}$ ratios were determined using a Finnigan MAT delta $\mathrm{S}$ type stable isotope ratio mass spectrometer. The results are given in the conventional $\delta$ value $\left(\delta=\left(R_{\text {sample }} / R_{\text {standard }}-1\right)^{*} 1000\right.$, where $R_{\text {sample }}$ and $R_{\text {standard }}$ are the ${ }^{13} \mathrm{C} /{ }^{12} \mathrm{C}$ ratios in the sample and standard, respectively) relative to V-PDB in \%o. Based on sample reproducibility and differences in $\delta^{13} \mathrm{C}$ values obtained for standards from their theoretical values, the accuracy is better than $\pm 0.1 \%$ for $\delta^{13} \mathrm{C}$.

\section{Results and discussion}

The $\delta^{13} \mathrm{C}$ values of the samples range between -28.6 and $-20.9 \%$ (Table 1 ). Figure 1 shows the distribution of $\delta^{13} \mathrm{C}$ values in the archaeological sites.

Graphitic samples from Szúr show the largest variation in their $\delta^{13} \mathrm{C}$ values, the ceramics from Szajk show a smaller variation, while the sherds from Dunaszentgyörgy show the smallest variation with $\delta^{13} \mathrm{C}$ values ranging between 
-26.0 and $-24.1 \%$. In the sample sets three groups can be distinguished on the basis of $\delta^{13} \mathrm{C}$ data (Fig. 1). Their separation is good at Szajk (from -28.6 to $-27.9 \%$; from -26.2 to $-25.6 \%$; $-23.8 \%$ ) and Szû́r (from -28.5 to $-27.0 \%$; from -25.6 to $-22.7 \%$; from -21.2 to $-20.9 \%$ ) and slightly weaker at Dunaszentgyörgy (from -26.0 to $-25.8 \%$; from -25.4 to $-24.9 \%$; $-24.1 \%$ ). However, the separation of data groups may disappear if the number of analysed samples increases.

The observed variability in carbon isotope data was not detected in the petrographic or mineralogical characteristics of graphite. The wide range of $\delta^{13} \mathrm{C}$ values may suggest that the graphitic raw material (graphitic rock) was not homogeneous in its carbon isotope composition or fractionation/ isotope shift occurred during pottery making (firing) or after the burial (interaction with fluids). Based on the $X$-ray diffraction analyses the firing of the sherds was carried out in general at a maximum of about $850{ }^{\circ} \mathrm{C}$ in reducing atmosphere with short duration (Havancsák et al. 2009a). Graphite can suffer kinetic fractionation related to partial oxidation during the firing process if it is not fully-ordered, which should occur at a temperature of around $500{ }^{\circ} \mathrm{C}$ (Landis 1971). It is presumable that the studied graphite is well-ordered based on the mineralogical assemblage of graphitic rock fragments in the ceramics: the used graphitic rock is a medium- to high-grade (amphibolite facies) metamorphic gneiss. Thus, kinetic fractionation effect can be neglected. However, isotope exchange may occur if carbonate is present. Argillic raw material mixed with the graphitic rock has usually up to 6 wt \% CaO content (Havancsák et al. 2009a). The carbon isotope composition of graphite could change through exchange reactions with carbonate (e.g. Bottinga 1969). Contrarily, Chacko et al. (1991) report that an experiment run at $800{ }^{\circ} \mathrm{C}$ and $15 \mathrm{kbar}$ for 170 hours produced essentially no isotope exchange between calcite and graphite. The firing process of the ceramics was probably shorter than the above-mentioned experimental time. In addition Wada and Suzuki (1983) suggest
Table 1

The $\delta^{13} \mathrm{C}$ values of the studied graphitic

\begin{tabular}{|c|c|c|}
\hline Sampling site & Sample & $\delta^{13} \mathrm{C}(\%)$ \\
\hline \multirow[t]{14}{*}{ Szür } & ő.2009.65.59.1. & -20.9 \\
\hline & ö.2009.65.64.309. & -20.9 \\
\hline & ő.2009.65.51.6. & -21.0 \\
\hline & ő.2009.65.11.26. & -21.2 \\
\hline & R.2009.65.28.14. & -22.7 \\
\hline & ő.2009.65.97.3. & -22.7 \\
\hline & ö.2009.65.56.51. & -23.5 \\
\hline & ö.2009.65.164.38. & -24.0 \\
\hline & ö.2009.65.56.87. & -24.7 \\
\hline & ő.2009.65.56.81. & -25.6 \\
\hline & ö.2009.65.166.77. & -27.0 \\
\hline & ő.2009.65.169.13. & -27.0 \\
\hline & R.2009.65.2.5 & -27.9 \\
\hline & R.2009.65.2.3. & -28.5 \\
\hline \multirow[t]{7}{*}{ Szajk } & ő.2006.73.53.38. & -23.8 \\
\hline & ö. 2006.73.53.37. & -25.6 \\
\hline & ö. 2006.73 .135 .53 . & -26.1 \\
\hline & ő.2006.73.135.51. & -26.2 \\
\hline & ö.2006.73.134.2. & -27.9 \\
\hline & ő.2006.73.20.129. & -28.4 \\
\hline & ö.2006.73.53.39. & -28.6 \\
\hline \multirow{11}{*}{$\begin{array}{l}\text { Dunaszent- } \\
\text { györgy }\end{array}$} & GRDSZGY-14 & -24.1 \\
\hline & GRDSZGY-3 & -24.9 \\
\hline & GRDSZGY-20 & -24.9 \\
\hline & GRDSZGY-19 & -25.0 \\
\hline & GRDSZGY-6 & -25.1 \\
\hline & GRDSZGY-2 & -25.2 \\
\hline & GRDSZGY-12 & -25.3 \\
\hline & GRDSZGY16 & -25.4 \\
\hline & GRDSZGY-11 & -25.8 \\
\hline & GRDSZGY-8 & -25.9 \\
\hline & GRDSZGY-4 & -26.0 \\
\hline
\end{tabular}


that armouring of graphite by silicate minerals can hinder the isotope exchange between graphite and carbonate. Graphite grains in the texture of the studied ceramics are surrounded by silicate minerals, such as quartz, K-feldspar, mica, kyanite and sillimanite. Isotope exchange after the burial is not likely. Jüntgen and Karweil (1966) show that there is no isotope shift below temperatures of $100-150{ }^{\circ} \mathrm{C}$, even if we disregard the above-mentioned "silicate armour effect" that blocks the isotope exchange.

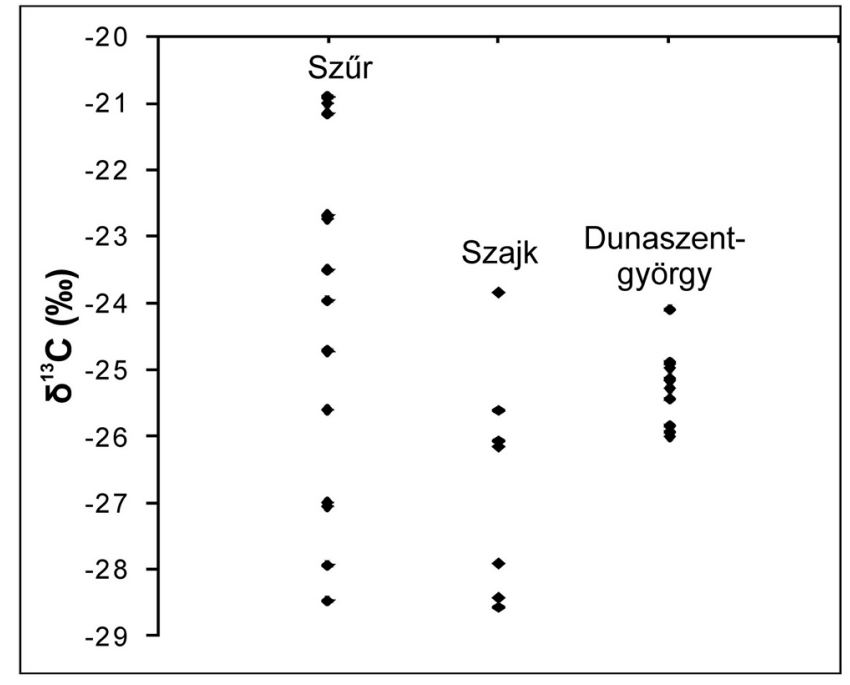

Fig. 1

The distribution of $\delta^{13} \mathrm{C}$ values of graphite in each archaeological site

Isotope shifts during the pottery manufacturing process and after the burial can be excluded and we suggest that the measured carbon isotope composition of graphite is characteristic for the graphitic metamorphic gneiss.

The carbon isotope composition of graphite provides information about its genesis (e.g. Craig 1953; Galimov 1975). Based on the obtained values, the studied graphite temper is supposed to be syngenetic carbon material, i.e. formed through the metamorphic evolution of organic matter. The metamorphic origin of graphite is in good correspondence with the petrographic observations.

\section{Conclusions}

Carbon isotope analysis of graphite in Celtic ceramics revealed a wide range of $\delta^{13} \mathrm{C}$ values. The observed variability suggests that the graphitic raw material used for tempering of pottery was not homogeneous in its carbon isotope composition. Kinetic fractionation effect and isotope exchange between graphite and carbonate in the pottery can be neglected. The measured $\delta^{13} \mathrm{C}$ values are supposed to be characteristic for the metamorphic gneiss containing syngenetic (metamophic) graphite. 
The applicability of carbon isotope analysis for provenance determination of graphite temper in archaeological ceramics will be evaluated in the next stage of research.

\section{References}

Bottinga, Y. 1969: Calculated fractionation factors for carbon and hydrogen isotope exchange in the system calcite-carbon dioxide-graphite-methane-hydrogen-water vapor. - Gecohimica et Cosmochimica Acta, 33, pp. 49-64.

Chacko, T., T.K. Mayeda, R.N. Clayton, J.R. Goldsmith 1991: Oxygen and carbon isotope fractionation between $\mathrm{CO}_{2}$ and calcite. - Geochimica et Cosmochimica Acta, 55, pp. 2867-2882.

Craig, H. 1953: The geochemistry of the stable carbon isotopes. - Geochimica et Cosmochimica Acta 3, pp. 53-92.

Galimov, E.M. 1975: Carbon isotopes in oil and gas geology. NASA translation TTF-682, Washington.

Havancsák, I., B. Bajnóczi, M. Tóth, A. Kreiter, Sz. Szöllősi 2009a: Kelta grafitos kerámia: elmélet és gyakorlat dunaszentgyörgyi kerámiák ásványtani, petrográfiai és geokémiai vizsgálatának tükrében (Celtic graphitic pottery: theory and practice in the light of mineralogical, petrographic and geochemical study of ceramics from Dunaszentgyörgy [S-Hungary]). Archeometriai Múhely, VI/1, pp. 39-51. (In Hungarian.)

Havancsák, I., B. Bajnóczi, Gy. Szakmány, A. Keiter, Sz. Szöllősi, Cs. Gáti 2009b: A petrográfiai vizsgálatok jelentôsége a kelta kerámiák grafitos soványítóanyagának proveniencia meghatározásában (Significance of petrographic investigations in the determination of provenance of graphitic temper in Celtic ceramics). - Archeometriai Múhely, VI/4, pp, 1-14. (In Hungarian.)

Jüntgen, H., J. Karweil 1966: Gasbildung und Gasspeicherung in Steinkohlenflözen. I: Gasbildung. Erdöl Kohle, 19, pp. 251-258.

Landis, C.A. 1971: Graphitization of dispersed carbonaceous material in metamorphic rocks. Contribution to Mineralogy and Petrology, 30, pp. 34-35.

Sofer, Z. 1980 Preparation of carbon dioxide for stable carbon isotope analysis of petroleum fractions. - Analytical Chemistry, 52, pp. 1389-1391.

Szabó, M., JP. Guillaumet, B. Kriveczky 1999: Polgár-Király-érpart vaskori település a Kr .e. IV-III. évszázadban (Polgár-Király-érpart Iron Age settlement in the 4th-3rd cent. B.C). - A debreceni Déri Múzeum Évkönyve, 1997/1998, pp. 177-181. (In Hungarian.)

Wada, H., K. Suzuki 1983: Carbon isotope thermometry calibrated by dolomite-calcite solvus temperatures. - Geochimica et Cosmochimica Acta, 47, pp. 697-706. 